Jurnal Konstruksi Hukum | ISSN: XXXX | E-ISSN: XXXX Vol. 1, No. 1, September 2020 Hal. 115-119| Available online at https://www.ejournal.warmadewa.ac.id/index.php/jukonhum

DOI: https://doi.org/10.22225/jkh.1.1.2142.115-119

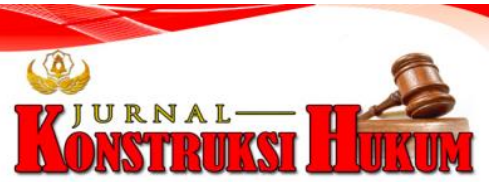

\title{
PENEGAKAN HUKUM TERHADAP PEMBUANGAN LIMBAH CAIR OLEH USAHA GARMEN DI KABUPATEN GIANYAR
}

\author{
Gede Krisna Adi Putra, I Putu Gede Seputra, Luh Putu Suryani \\ Fakultas Hukum Universitas Warmadewa, Denpasar - Bali, Indonesia
}

\begin{abstract}
Abstrak
Kabupaten Gianyar merupakan satu dari sekian banyak kabupaten di Bali yang menjadi favorit wisatawan. Banyak dari wisatawan tersebut yang tertarik akan produk garmen lokal, sehingga banyak industri garmen sekala kecil berkembang. Namun dari banyaknya industri garmen tersebut masih banyak yang kurang peduli dengan membuang limbah cair hasil produksi garmennya begitu saja tanpa mengolahnya terlebih dahulu agar lebih ramah. Berdasarkan latar belakang tersebut, penelitian ini dilakukan dengan tujuan menggambarkan bagaimana pengawasan pembuangan limbah cair oleh usaha garmen di Kabupaten Gianyar dan apa kendala penegakan hukum terhadap usaha garmen yang membuang limbah cair di Kabupaten Gianyar. Penelitian ini didesain dengan menggunakan metode hukum Empiris. Penelitian ini di lakukan di Kabupaten Gianyar. Hasil penelitian ini menunjukkan bahwa pengawasan pembuangan limbah cair di Kabupaten Gianyar dilakukan oleh Dinas Lingungan Hidup Kabupaten Gianyar dengan mekanisme memeriksa dokumen-dokumen yang dimiliki oleh pemilik usaha garmen tersebut. Kemudian, menyusun laporan hasil pengawasan berdasarkan fakta dan temuan lapangan. Terakhir, Dinas Lingkungan Hidup Kabupaten Gianyar membuat rekomendasi dan menyampaikan rekomendasi hasil pengawasan. Kendala penegakan hukum terhadap usaha garmen yang membuang limbah cair di Kabupaten Gianyar, yaitu: sarana hukum, aparat penegak hukum, fasilitas dan sarana, perizinan, kesadaran hukum masyarakat.
\end{abstract}

Kata kunci: Limbah cair; Penegakan hukum; Usaha garmen

\begin{abstract}
Gianyar Regency is one of the districts in Bali which is a favorite of tourists. Many of these tourists are interested in local garment products, so many small garment industries are developing. However, of the many garment industries there are still many who are less concerned with disposing of the liquid waste produced by the garment without processing it first to make it more eco-friendly. Based on this background, this research was conducted with the aim of describing how to monitor the disposal of liquid waste by garment businesses in Gianyar Regency and what are the obstacles to law enforcement against garment businesses that dispose of liquid waste in Gianyar Regency. This research was designed using the empirical legal method. This research was conducted in Gianyar Regency. The results of this study indicated that the supervision of liquid waste disposal in Gianyar Regency was carried out by the Environmental Service Office of Gianyar Regency by checking the documents owned by the garment business owner. Then, they compiled a monitoring report based on facts and field findings. Finally, the Gianyar Regency Environmental Service made recommendations and submitted recommendations on the results of the supervision. The barriers to law enforcement against garment businesses that dispose of liquid waste in Gianyar Regency are legal facilities, law enforcement officers, facilities and facilities, permits, public legal awareness.
\end{abstract}

Keywords: Liquid waste; Law enforcement; Garment business

\section{PENDAHULUAN}

Indonesia merupakan salah satu negara berkembang yang saat ini sedang melakukan pembenahan di dalam bidang pembangunan infrastruktur serta ekonomi. Pembangunan tersebut bukan hanya serta merta untuk golongan tertentu saja, tapi untuk kemakmuran serta kesejahteraan seluruh rakyat. Untuk menopang hal tersebut pemerintah melakukan kegiatan pengiriman barang ke luar negeri untuk memberi tambahan penerimaan devisa dan pendapatan negara. Salah satu komoditas andalan ekspor Indonesia adalah tekstil yang dihasilkan oleh industri garmen. Industri garmen di Indonesia terus berkembang mulai dari pabrik-pebrik garmen sampai dengan tingkat UKM (Warni \& Setyarni, 2019; Wulandari, 2012). 
Kabupaten Gianyar merupakan salah satu Kabupaten yang banyak dikunjungi wisatawan baik luar negeri maupun dalam negeri. Ada banyak wisatawan yang tertarik dengan kain - kain garmen, sehingga menyebabkan banyak berkembangnya industri skala kecil. Namun masih banyak industri garmen di Kabupaten Gianyar yang kurang peduli akan lingkungan sekitar dengan membuang limbah cair hasil produksi garmennya begitu saja di sungai tanpa melakukan pengolahan lebih lanjut terlebih dahulu sebelum membuangnya.

Izin usaha mudah diperoleh apabila persyaratan sudah sesuai dengan ketentuan yang berlaku. Setelah mendapatkan izin usaha juga harus memiliki izin pembuangan limbah cair (Helmi, 2011; Wibisana, 2018; Wijoyo, 2012). Namun yang terjadi setelah mendapatkan izin usaha para pengusaha garmen mereka tidak melihat ketentuan yang berlaku yaitu Peraturan Bupati Gianyar Nomor 55 Tahun 2013 tentang Tata Cara Perizinan Lingkungan Yang Berkaitan Dengan Pembuangan Limbah Ke Sumber Air.

Limbah cair garmen merupakan limbah anorganik yang tidak dapat diuraikan oleh bakteri karena limbah cair garmen mengandung zat - zat yang berbahaya (B. \& Mallongi, 2018; Doraja, Shovitri, \& Kuswytasari, 2012; Dwi Adhi S, Simpen, \& Putra, 2017). Oleh karena itu, limbah cair dari usaha garmen dapat mencemari karena zat - zat yang tidak dapat diurai oleh bakteri tersebut akan terus mengendap di dalam air dan limbah cair garmen ini juga mengandung zat pewarna, sehingga membuat warna air ikut berubah dan menjadi tercemar.

Berdasarkan uraian di atas, penelitian ini dilakukan dengan tujuan menggambarkan bagaimana pengawasan pembuangan limbah cair oleh usaha garmen di Kabupaten Gianyar dan apa kendala penegakan hukum terhadap usaha garmen yang membuang limbah cair di Kabupaten Gianyar.

\section{METODE PENELITIAN}

Metode penelitian adalah rangkaian tindakan dengan alur pemikiran yang sistematis untuk mencapai suatu tujuan dalam penyusunan penelitian, dengan cara mencari, mencatat merumuskan, dan menganalisa, sampai menyusun laporan. Penelitian ini didesain dengan menggunakan pendekatan hukum empiris dan juga menggunakan pendekatan yuridis sosiologis. Sumber data penelitian ini adalah Pengawas Lingkungan Hidup Daerah Kabupaten Gianyar dan pemilik industri garmen. Data dikumpulkan dengan menggunakan metode wawancara atau interview. Metode ini digunakan untuk memperoleh fakta - fakta dan data yang terjadi. Penelitian ini dilakukan di Kabupaten Gianyar. Selanjutnya, data yang terkumpul dianalisis secara kualitatif dan disajikan secara deskriptif menggunakan metode formal dan informal.

\section{HASIL DAN PEMBAHASAN}

\section{Pengawasan Pembuangan Limbah Cair oleh Usaha Garmen di Kabupaten Gianyar}

Mekanisme adalah cara untuk mendapatkan sesuatu secara teratur sehingga menghasilkan suatu pola atau bentuk untuk mencapai tujuan yang diinginkan. Dinas Hidup Kabupaten Gianyar melakukan pengawasan yang berdasarkan Bab V Pembinaan Dan Pengawasan Pasal 31 Peraturan Bupati Gianyar Nomor 55 Tahun 2013, menyebutkan "Dalam melaksanakan pembinaan dan pengawasan sebagai mana dimaksud dalam Pasal 30 ayat 2, Kepala Dinas Lingkungan Hidup harus:

a. melakukan pengujian kualitas air limbah yang dibuang atau dimanfaatkan oleh suatu kegiatan usaha,

b. melakukan pemeriksaan terhadap sarana dan prasarana pengolahan air limbah,

c. melakukan pengumpulan bahan keterangan untuk bahan penegakan hukum,

d. memberikan peringatan terhadap pelanggaran ketentuan izin,

e. melaksanakan penutupan secara paksa saluran pembuangan air limbah yang membahayakan kepentingan umum dan / atau mencemari lingkungan,

f. meminta data dan keterangan pengolahan air limbah yang dilaksanakan oleh suatu kegiatan usaha,

g. mensosialisasikan ketentuan Peraturan Bupati ini,

h. melaksanakan pemantauan dan pemeriksaan kualitas air dan sumber-sumber air,

i. melaksanakan upaya pencegahan terjadinya pencemaran air, dan

j. memberikan pembinaan dalam penyediaan sarana pengolahan air limbah bagi usaha dan / atau yang membuang dan / atau memanfaatkan limbah. 
Berdasarkan wawancara langsung dengan Pengawas Lingkungan Hidup Daerah Kabupaten Gianyar, Wayan Adi Putra Guanawan menerangkan bahwa pengawasan penaatan lingkungan hidup terhadap usaha dan/atau kegiatan dilakukan di Kabuapten Gianyar yang dilaksanakan sejak bulan Februari sampai bulan November 2018. Pengawasan dilakukan oleh Tim Pengawasan Lingkungan Hidup berdasarkan SK Bupati Gianyar Nomor : 164/E-06/HK/2018, tanggal 2 Januari 2018, tentang pembentukan Tim Pengawasan Lingkungan di Kabupaten Gianyar Tahun 2018 yang beranggotakan Pejabat Pengawas Lingkungan Hidup Daerah (PPLHD) di Dinas Lingkungan Hidup Gianyar, Bidang Pemantauan dan Penendalian Pencemaran Dinas Lingkungan Hidup Kabupaten Gianyar, Unsur Dinas/Instansi terkait, Unsur Kepolisian, Unsur Kejaksaan.

Pelaksanaan kegiatan pengawasan penaatan lingkungan hidup terhadap industri serta aktivitas dilakukan dengan cara melakukan inspeksi langsung ke lapangan, yaitu dengan melakukan pemeriksaan terhadap dokumen lingkungan serta izin-izin yang terkait, pemeriksaan fasilitas pengelolaan air limbah, pemeriksaan terhadap fasilitas pengelolaan sumber emisi, memeriksa tempat penyimpanan limbah B3 serta pengelolaannya, membuat catatan temuan-temuan lapangan, meminta keterangan dari pihak perusahaan mengenai pengelolaan lingkungan yang dilakukan, membuat berita acara hasil pengawasan, menyusun laporan hasil pengawasan, membuat dan menyampaikan rekomendasi hasil pengwasan.

Batas baku mutu limbah cair yang ditetapkan Dinas Lingkungan Hidup adalah sebagai berikut.

\begin{tabular}{|l|c|c|}
\hline \multicolumn{1}{|c|}{ PARAMETER } & $\begin{array}{c}\text { KADAR } \\
\text { MAKSIMUM } \\
(\mathrm{mg} / \mathrm{L})\end{array}$ & $\begin{array}{c}\text { BEBAN } \\
\text { PENCEMARAN } \\
\text { MAKSIMUM } \\
(\mathrm{kg} / \mathrm{ton})\end{array}$ \\
\hline BOD $_{5}$ & 85 & 12,75 \\
\hline COD & 250 & 37,5 \\
\hline TSS & 60 & 9,0 \\
\hline Fenol Total & 1,0 & 0,15 \\
\hline Krom Total $(\mathrm{Cr})$ & 2,0 & 0,30 \\
\hline Minyak dan Lemak & 5,0 & 0,75 \\
\hline pH & \multicolumn{2}{|c|}{$6,0-9,0$} \\
\hline $\begin{array}{l}\text { Debit Limbah } \\
\text { Maksimum }\end{array}$ & $150 \mathrm{~m}^{3}$ per ton produk tekstil \\
\hline
\end{tabular}

Kegiatan pengawasan pendatangan hidup terhadap usaha atau kegiatan di wilayah Kabupaten Gianyar, terdiri dari hotel, industri, rumah sakit, rumah makan, pemotongan ayam, peternakan babi dan Taman Rekreasi.

Dalam melakukan kegiatan pengawasan pembuangan limbah cair Dinas Lingkungan Hidup kabupaten Gianyar memiliki beberapa kriteria pengelolaan limbah cair yang diberikan kepada industri yang dalam kegiatan usahanya menghasilkan limbah cair berikut.

1. wajib mengolah air limbah

2. wajib memenuhi baku mutu

3. wajib membuat SOP tanggap darurat

4. wajib memiliki sarana penanggulangan keadaan darurat

5. wajib melakukan pemantauan

6. wajib melaporkan hasil pemantauan

7. wajib memasang alat ukur debit

8. larangan melakukan pencemaran

9. larangan melakukan pembuangan secara sekaligus.

Berdasarkan fakta di lapangan masih terdapat industri garmen yang membuang limbah cair tanpa melakukan pengolahan terlebih dahulu. Berdasarkan wawancara salah satu pemilik industri garmen, yaitu Bapak Ketut Sujatra, ia menyatakan alasannya masih membuang limbah begitu saja ke sungai dikarenakan untuk menekan pengeluaran industri dimana biaya dalam pengolahan limbah cukup tinggi.

Tahapan kegiatan dalam melakukan pengawasan pendatangan lingkungan hidup terhadap industri serta aktivitas adalah sebagai berikut. 
1. Berkirim surat kepada penanggung jawab usaha mengenai kegiatan dan/atau mengenai jadwal pelaksanaan pengawasan beserta agenda pengawasan.

2. Persiapan pengawasan (mempelajari dokumen terkait, menyusun tim pengawas, menyiapkan peralatan, menyusun check list, membuat agenda pengawasan dan membuat surat penugasan serta persiapan administrasi lainnya).

3. Pelaksanaan pengawasan lapangan (pemeriksaan izin (dokumen ), izin perlindungan dan pengelolaan (Izin PPLH), pemeriksaan pengelolaan air limbah, pemeriksaan instalasi genset/ /boiler atau emisi udara, dan pengelolaan limbah B3).

4. Pembuatan Berita Acara dan Penandatanganan Berita Acara.

5. Menyusun laporan hasil pengawasan berdasarkan fakta dan temuan lapangan.

6. Membuat rekomendasi.

7. Menyampaikan rekomendasi hasil pengawasan pemilik usaha.

\section{Kendala Penegakan Hukum terhadap Pembuangan Limbah Cair oleh Usaha Garmen di Kabupaten Gianyar}

Ditemukan berbagai halangan yang menimbulkan tidak efektivitasnya faktor pendukung dalam penegakan hukum. Banyak peraturan-peraturan yang telah dikeluarkan oleh pemerintah kabupaten Gianyar, namun pelaksanaannya di lapangan masih ada kendala yang ditemui yaitu sebagai berikut.

1. Sarana Hukum

Salah satu faktor penghambat dalam penegakan hukum adalah Sarana hukum. Dikarenakan sering kali terjadi ketidak konsistenan dengan prinsip - prinsip pengelolaan dan perlindungan lingkungan hidup. Berbagai kebijakan operasional yang dikeluarkan didalam Undang-Undang yang berkaitan dengan pengelolaan dan perlidungan lingkungan hidup. Dalam upaya penegakan hukum, faktor penting dalam keberhasilan penegakan hukum yaitu pelaksanaan dari manusianya itu sendiri dibandingkan dengan faktor hukum itu sendiri.

2. Aparat Penegak Hukum

Masih sangat terbatasnya jumlah aparat penegak hukum profesional yang mampu menangani kasus - kasus. Disamping itu mustahil untuk para penegak hukum dapat menguasai semua aspek, karena aspek yang sangat luas dan komplek dari lingkungan hidup itu sendiri. Keterbatasan pengetahuan dan pemahaman aspek - aspek oleh penegak hukum menjadi faktor kendala yang sangat dominan dalam upaya untuk menciptakan kesamaan persepsi penanganan perkara.

3. Fasilitas dan Sarana

Untuk mencapai tujuan penegakan hukum di perlukan Fasilitas dan sarana sebagai alatnya. Keterbatasan atau ketiadaan fasilitas, sarana penunjang dan dana akan sangat berpengaruh atas keberhasilan penegakan hukum. Dalam penanganan kasus - kasus tersebut diantaranya akan menggunakan berbagai alat berteknologi canggih seperti peralatan laboratorium dimana memerlukan tenaga ahli dan biaya cukup mahal.

4. Perizinan

Salah satu bidang yang banyak memberi peluang bagi berkembangnya masalah ketimbang membatasinya yaitu di bidang perizinan. dimana Pasal 36 Undang-Undang Nomor 32 Tahun 2009 masih bisa dilewati begitu saja oleh pengusaha, apalagi jika izin yang dimaksud adalah izin yang akan diberikan oleh Dinas Perizinan, setelah suatu perusahaan siap berproduksi.

5. Kesadaran Hukum Masyarakat

Di samping keberadaan penegak hukum, peran serta masyarakat merupakan komponen utama untuk tercapainya tujuan hukum serta diimbangi sarana penegak hukum yang baik menurut undang-undang pengelolaan hidup. Masih minimnya kepedulian masyarakat terhadap lingkungan sekitar yang dikarenakan oleh ketidaktahuan masyarakat terhadap akibat yang akan timbul bila melakukan pencemaran dan perusakan terhadap lingkungan hidup. Untuk itu perlu dilakukan penyuluhan, bimbingan, dan keterlibatan masyarakat dalam pelestarian alam perlu ditingkatkan lagi. 


\section{SIMPULAN}

Berdasarkan hasil dan pembahasan yang telah diuraikan di atas, ada beberapa simpulan yang dapat dibuat, yaitu: pertama, pengawasan pembuangan limbah cair di Kabupaten Gianyar dilakukan oleh Dinas Lingungan Hidup Kabupaten Gianyar dengan mekanisme memeriksa dokumen-dokumen yang dimiliki oleh pemilik usaha garmen tersebut. Kemudian, menyusun laporan hasil pengawasan berdasarkan fakta dan temuan lapangan. Terakhir, Dinas Lingkungan Hidup Kabupaten Gianyar membuat rekomendasi dan menyampaikan rekomendasi hasil pengawasan. Kedua, ada beberapa kendala dalam penegakan hukum terhadap usaha garmen yang membuang limbah cair di Kabupaten Gianyar, yaitu: sarana hukum, aparat penegak hukum, fasilitas dan sarana, perizinan, dan kesadaran hukum masyarakat.

\section{DAFTAR PUSTAKA}

B., R., \& Mallongi, A. (2018). Studi Karakteristik dan Kualitas BOD dan COD Limbah Cair Rumah Sakit Umum Daerah Lanto DG. Pasewang Kabupaten Jeneponto. Jurnal Nasional Ilmu Kesehatan, 1(1), 1-16.

Doraja, P. H., Shovitri, M., \& Kuswytasari, N. D. (2012). Biodegradasi Limbah Domestik dengan Menggunakan Inokulum Alami dari Tangki Septik. Jurnal Sains Dan Seni ITS, 1(1), 44-47.

Dwi Adhi S, N. G. A. M., Simpen, I. N., \& Putra, A. A. B. (2017). Reduksi Komponen Toksik dari Limbah Cair Garmen Menggunakan Bio-Anorganik-Sorben Arang Tulang. CAKRA KIMIA (Indonesian E-Journal of Applied Chemistry), 5(1), 18-25.

Helmi. (2011). Kedudukan Izin Lingkungan dalam Sistem Perizinan di Indonesia. Jurnal Ilmu Hukum, 2(2).

Warni, G. S., \& Setyarni, N. P. W. (2019). Analisis Daya Saing Ekspor Pakaian Jadi Indonesia ke Pasar Jerman Periode Tahun 2013-2018. E-Jurnal EP Unud, 8(11), 2656-2688.

Wibisana, A. G. (2018). Pengelolaan Lingkungan melalui Izin Terintegrasi dan Berantai: Sebuah Perbandingan atas Perizinan Lingkungan di Berbagai Negara. Jurnal Hukum \& Pembangunan, 48(2), 222-225.

Wijoyo, S. (2012). Persyaratan Perizinan Lingkungan dan Arti Pentingnya bagi Upaya Pengelolaan Lingkungan di Indonesia. Yuridika, 27(2), 97-110.

Wulandari, L. D. (2012). Analisis Dampak Impor Cina terhadap Kebertahanan dan Pertumbuhan Industri Tekstil dan Produksi Tekstil Indonesia. Jurnal Ekonomi Dan Pembangunan Indonesia, 13(1), 90-108. 